\title{
The lateral parabrachial nucleus and central angiotensinergic mechanisms in the control of sodium intake induced by different stimuli
}

\author{
Camila F. Roncari ${ }^{1}$, Richard B. David ${ }^{1}$, Patrícia M. De Paula, Débora S.A. Colombari, \\ Laurival A. De Luca Jr., Eduardo Colombari, José V. Menani* \\ Department of Physiology and Pathology, School of Dentistry, São Paulo State University, UNESP, Araraquara, SP, Brazil
}

\section{A R T I C L E I N F O}

\section{Keywords:}

Angiotensin II

$\mathrm{AT}_{1}$ receptors

Cholinergic receptors

Osmoreceptor

Sodium appetite

\begin{abstract}
A B S T R A C T
Angiotensin II (ANG II) is a typical facilitatory stimulus for sodium appetite. Surprisingly, hyperosmolarity and central cholinergic stimulation, two classical antinatriorexigenic stimuli, also facilitate $\mathrm{NaCl}$ intake when they are combined with injections of the $\alpha_{2}$-adrenoceptor/imidazoline agonist moxonidine into the lateral parabrachial nucleus (LPBN). In the present study, we tested the relative importance of central angiotensinergic and cholinergic mechanisms for the control of water and $\mathrm{NaCl}$ intake by combining different dipsogenic or natriorexigenic stimuli with moxonidine injection into the LPBN. Adult male Holtzman rats (n = 9-10/group) with stainless steel cannulas implanted in the lateral ventricle and LPBN were used. Bilateral injections of moxonidine $(0.5 \mathrm{nmol})$ into the LPBN increased water and $0.3 \mathrm{M} \mathrm{NaCl}$ intake in rats that received furosemide + captopril injected subcutaneously, ANG II $(50 \mathrm{ng})$ or carbachol (cholinergic agonist, $4 \mathrm{nmol})$ injected intracerebroventricularly (icv) or $2 \mathrm{M} \mathrm{NaCl}$ infused intragastrically ( $2 \mathrm{ml} / \mathrm{rat}$ ). Losartan ( $\mathrm{AT}_{1}$ antagonist, $100 \mu \mathrm{g}$ ) or atropine (muscarinic antagonist, $20 \mathrm{nmol}$ ) injected icv abolished the effects on water and $0.3 \mathrm{M} \mathrm{NaCl}$ of moxonidine combined to either $2 \mathrm{M} \mathrm{NaCl}$ intragastrically or carbachol icv. However, atropine icv did not change $0.3 \mathrm{M} \mathrm{NaCl}$ intake produced by direct central action of ANG II like that induced by ANG II icv or furosemide + captopril combined with moxonidine into the LPBN. The results suggest that different stimuli, including hyperosmolarity and central cholinergic stimulation, share central angiotensinergic activation as a common mechanism to facilitate sodium intake, particularly when they are combined with deactivation of the LPBN inhibitory mechanisms.
\end{abstract}

\section{Introduction}

Forebrain and hindbrain areas interconnect forming a circuitry that integrates facilitatory and inhibitory mechanisms to control sodium and water intake [1-4]. The facilitation is counterbalanced by inhibitory mechanisms activated by signals that arise from visceral receptors, such as baroreceptors, taste receptors or osmoreceptors [1,3-5].

Tradition in the field has established that some models of dehydration may result in the expression of both water and sodium intake, whereas other models of dehydration induce thirst and inhibit of sodium intake. For example, during extracellular dehydration or hypovolemia, central angiotensinergic mechanisms are activated, and angiotensin II (ANG II) is a facilitatory signal to both water and sodium intake [1-7]. However, intracellular dehydration or hyperosmolarity, which activates osmoreceptors or brain acetylcholine are facilitatory to water intake, but have the potential to inhibit sodium intake [8-16].

Previous studies have indicated that ANG II and acetylcholine may interact to control bodily-fluid balance. For example, the antagonism of ANG II $\mathrm{AT}_{1}$ receptors inhibits thirst induced by brain cholinergic activation [17]. The same kind of antagonism also inhibits hypertension, vasopressin secretion and natriuresis induced by either brain cholinergic activation or hyperosmolarity [18-25]. Therefore, activation of angiotensinergic mechanisms seems to be important for some of the responses induced by cholinergic activation. In this case, the two distinct mechanisms interact to produce similar behavior or a physiological response.

It is more difficult to understand and admit the interaction when the mechanisms are suggested to produce opposite effects in the same behavioral response. As mentioned above, ANG II is facilitatory to sodium intake and brain cholinergic activation may inhibit sodium intake,

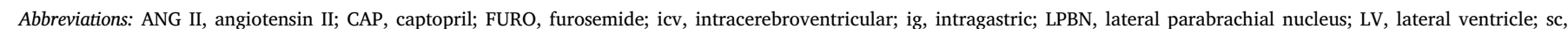
subcutaneous

* Corresponding author at: Department of Physiology and Pathology, School of Dentistry, São Paulo State University, UNESP, 14801-903, Araraquara, SP, Brazil.

E-mail address: menani@foar.unesp.br (J.V. Menani).

${ }^{1}$ Present address: Department of Physiology and Pharmacology, School of Medicine, Federal University of Ceará, Fortaleza, CE, Brazil. 
which might indicate that no interaction exists between these two mechanisms for the expression of this behavior. However, the blockade of the inhibitory mechanisms with injections of methysergide into the lateral parabrachial nucleus (LPBN) combined with central cholinergic activation induces $\mathrm{NaCl}$ intake, which suggests that this stimulus classically considered antinatriorexigenic also causes a facilitation of sodium intake [26]. In addition, recently it has been shown that forebrain activation of either ANG II or cholinergic receptors facilitates sodium intake in rats treated with GABA agonist injection into the LPBN, suggesting that sodium intake in this condition seems to depend on the activation of angiotensinergic and cholinergic receptors [27-29]. Therefore, the possibility that ANG II and brain cholinergic activation also interact to facilitate sodium intake in dehydrated rats needs to be addressed.

Several neurotransmitters modulate the activity of LPBN inhibitory mechanisms involved in the control of sodium intake in a dehydrated rat $[28,30-34]$. For example, the activation of the $\alpha_{2}$-adrenoceptors with injections of moxonidine into the LPBN blocks the inhibitory mechanisms and, thereby, potentiate the typical $0.3 \mathrm{M} \mathrm{NaCl}$ intake induced by hypovolemia or ANG II [35-37]. Surprisingly, similar injections into the LPBN combined with hyperosmolarity elicit a paradoxical and substantial $0.3 \mathrm{M} \mathrm{NaCl}$ intake, which reinforces the idea that a stimulus classically considered antinatriorexigenic may also facilitate sodium intake $[38,39]$.

In the present study, we investigated whether central angiotensinergic and cholinergic mechanisms interact to produce sodium intake in two different models of dehydration: hypovolemia and hyperosmolarity combined with moxonidine injections into the LPBN. The hypovolemia model was produced by combining a subcutaneous (sc) injection of diuretic furosemide (FURO) with angiotensin converting enzyme inhibitor captopril (CAP). This treatment produces a quick sodium appetite as a result of hypovolemia and mild hypotension associated to rapid increase in brain formation of ANG II [40,41]. It was tested whether the cholinergic antagonist atropine injected intracerebroventricularly (icv) reduced sodium intake induced by combining FURO + CAP sc with moxonidine injected into the LPBN. In order to double check the effect of atropine in a model involving the angiotensinergic mechanism, it was also investigated whether this antagonist reduced sodium intake produced by combined injections of moxonidine into the LPBN and ANG II icv. In the hyperosmolarity model, rats received an intragastric (ig) load of $2 \mathrm{M} \mathrm{NaCl}$ combined with moxonidine into the LPBN to produce the paradoxical sodium intake [38]. The ANG II $\mathrm{AT}_{1}$ receptor antagonist losartan or atropine was injected icv in hyperosmotic rats treated with moxonidine into the LPBN. In addition, it was also investigated whether the antagonists reduced sodium intake produced by combined injection of moxonidine into the LPBN and carbachol, a cholinergic agonist, icv.

\section{Experimental procedures}

\subsection{Animals}

A total of 52 male Holtzman rats weighing 290-310 g were used. Animals were housed in individual stainless steel cages with free access to normal sodium diet (BioBase Rat Chow, Águas Frias, Brazil), water and $0.3 \mathrm{M} \mathrm{NaCl}$ solution. Room temperature was maintained at $23 \pm 2{ }^{\circ} \mathrm{C}$, humidity at $55 \pm 10 \%$, and on a $12: 12$ light-dark cycle. Rats had at least 5 days of free access to $0.3 \mathrm{M} \mathrm{NaCl}$ solution before tests. All experimental procedures were approved by Ethical Committee in Animal Use (CEUA) from School of Dentistry - UNESP (Proc. CEUA \# 01/2011). Experimental protocols followed U.S. National Institutes of Health Guide for the Care and Use of Laboratory Animals (NIH publication no. 80-23, 1996).

\subsection{Brain surgery}

Rats were anesthetized with ketamine $(80 \mathrm{mg} / \mathrm{kg}$ body wt; Cristália, Itapira, Brazil) combined with xylazine $(7 \mathrm{mg} / \mathrm{kg}$ body wt; Agener União, Embu-Guaçu, Brazil) intraperitoneally, placed in a stereotaxic instrument (Kopf, Tujunga, USA) with the skull leveled between bregma and lambda. Two stainless steel 23-gauge guide cannulas were implanted bilaterally immediately above the LPBN (coordinates: $9.6 \mathrm{~mm}$ caudal to bregma, $2.1 \mathrm{~mm}$ lateral to midline, and $3.1 \mathrm{~mm}$ below dura mater) and a third cannula was implanted immediately above the left lateral ventricular ( $\mathrm{LV}$; coordinates: $0.8 \mathrm{~mm}$ caudal to bregma, $1.6 \mathrm{~mm}$ lateral to midline, and $2.7 \mathrm{~mm}$ below the skull). The tips of the guide cannulas were positioned at a point $2 \mathrm{~mm}$ above the LPBN and $1 \mathrm{~mm}$ above the LV. Dental acrylic resin and jeweler screws were used to fix the guide cannulas to the cranium. A 30-gauge metal obturator filled the guide cannulas between tests. Animals received an intramuscular injection of antibiotic (benzylpenicillin - 80,000 IUs plus streptomycin - 33 mg; Pentabiótico Veterinário - Pequeno Porte, Fort Dodge Saúde Animal Ltda., Campinas, Brazil) and a sc injection of analgesic/anti-inflammatory (ketoprofen $1 \%-0.03 \mathrm{ml} / \mathrm{rat}$; Ketoflex, Mundo Animal, São Paulo, Brazil) at the end of surgery. Before starting water and $0.3 \mathrm{M} \mathrm{NaCl}$ intake tests, rats were allowed to recover from surgery for 5 days.

\subsection{Drugs}

Moxonidine hydrochloride, $\alpha_{2}$-adrenoceptor/imidazoline agonist (Sigma-Aldrich, St Louis, MO, USA) was dissolved in a mix of propylene glycol and water 2:1 (vehicle) and administered into the LPBN at the dose of $0.5 \mathrm{nmol} / 0.2 \mu \mathrm{l}$. Atropine methyl bromide $(20 \mathrm{nmol} / 1.0 \mu \mathrm{l}$; muscarinic cholinergic receptor antagonist), carbachol (4 nmol/1.0 $\mu \mathrm{l}$; cholinergic receptor agonist), losartan potassium $\left(100 \mu \mathrm{g} / 1.0 \mu \mathrm{l} ; \mathrm{AT}_{1}\right.$ receptor antagonist), and angiotensin II human $(50 \mathrm{ng} / 1.0 \mu \mathrm{l})$ were purchased from Sigma-Aldrich and administered into the LV dissolved in saline.

Furosemide (Sigma-Aldrich) was dissolved in alkaline saline $(\mathrm{pH}$ adjusted to 9.0 with $\mathrm{NaOH}$ ) and administered sc at $10 \mathrm{mg} / \mathrm{kg}$ body wt. Captopril (Sigma-Aldrich), angiotensin converting enzyme inhibitor, was dissolved in saline and administered sc at $5 \mathrm{mg} / \mathrm{kg}$ body wt.

\subsection{Central injections}

Hamilton syringes ( $5 \mu \mathrm{l}$; Hamilton, Reno, USA) connected by polyethylene tubing (PE-10; Clay Adams, Parsippany, USA) to a 30-gauge injection cannula were used for injections into LPBN and LV. At the time of testing, rats were removed from the cages, metal obturators were removed and the injection cannula ( $2 \mathrm{~mm}$ longer than the guide cannula) was inserted into the guide cannula. Injection volumes into the LPBN and LV were $0.2 \mu \mathrm{l}$ each site and $1.0 \mu \mathrm{l}$, respectively. Metal obturators were replaced and the rats were returned to their cages after injections.

\subsection{Water and $0.3 \mathrm{M} \mathrm{NaCl}$ intake tests}

\subsubsection{Tests in FURO + CAP-treated rats}

In a group of rats $(\mathrm{n}=9)$, water and $0.3 \mathrm{M} \mathrm{NaCl}$ intake was induced by sc injections of FURO ( $10 \mathrm{mg} / \mathrm{kg}$ body wt $)+$ CAP $(5 \mathrm{mg} / \mathrm{kg}$ body wt). Immediately after treatment with FURO + CAP, atropine (20 $\mathrm{nmol} / 1.0 \mu \mathrm{l}$ ) or saline was injected into the LV. Rats were maintained without water and $0.3 \mathrm{M} \mathrm{NaCl}$ for $1 \mathrm{~h}$. After this period, water and $0.3 \mathrm{M} \mathrm{NaCl}$ were offered to the animals and cumulative intake was recorded at $15,30,60,90$ and $120 \mathrm{~min}$. Vehicle or moxonidine $(0.5$ $\mathrm{nmol} / 0.2 \mu \mathrm{l})$ was injected into the LPBN $15 \mathrm{~min}$ before access to water and $0.3 \mathrm{M} \mathrm{NaCl}$. Sequence of treatments into the LV and LPBN was randomized and each rat received all three combinations of treatments: (1) saline into the LV + vehicle into the LPBN; (2) saline into the LV 
+ moxonidine into the LPBN; (3) atropine into the LV + moxonidine into the LPBN. A recovery period of at least 2 days was allowed between tests. During the tests rats had no access to food.

\subsubsection{Tests in fluid-replete rats}

Rats $(n=9)$ were tested in their home cages with no access to food during the test. Water and $0.3 \mathrm{M} \mathrm{NaCl}$ were provided from burettes with $0.1 \mathrm{ml}$ divisions that were fitted with metal drinking spouts. Animals received injections of atropine $(20 \mathrm{nmol} / 1.0 \mu \mathrm{l})$ or saline into the $\mathrm{LV}$ and moxonidine $(0.5 \mathrm{nmol} / 0.2 \mu \mathrm{l})$ or vehicle into the LPBN. Fifteen minutes later, ANG II $(50 \mathrm{ng} / 1.0 \mu \mathrm{l})$ was injected into the LV. Cumulative water and $0.3 \mathrm{M} \mathrm{NaCl}$ intake was recorded at 15, 30, 60, 90 and 120 min starting immediately after ANG II injection. The sequence of treatments into the LV and LPBN was randomized and each rat received all three combinations of treatments: (1) saline + ANG II into the LV + vehicle into the LPBN; (2) saline + ANG II into the LV + moxonidine into the LPBN; (3) atropine + ANG II into the LV + moxonidine into the LPBN.

Another group of animals $(\mathrm{n}=15)$ received injections of atropine $(20 \mathrm{nmol} / 1.0 \mu \mathrm{l})$, losartan $(100 \mu \mathrm{g} / 1.0 \mu \mathrm{l})$ or saline into the $\mathrm{LV}$ and moxonidine $(0.5 \mathrm{nmol} / 0.2 \mu \mathrm{l})$ or vehicle into the LPBN. Fifteen minutes later, carbachol $(4 \mathrm{nmol} / 1.0 \mu \mathrm{l})$ was injected into the LV. Cumulative water and $0.3 \mathrm{M} \mathrm{NaCl}$ intake was recorded at 15,30,60, 90 and 120 min starting immediately after carbachol injection. The sequence of treatments into the LV and LPBN was randomized and each rat received all four combinations of treatments: (1) saline + carbachol into the LV + vehicle into the LPBN; (2) saline + carbachol into the LV + moxonidine into the LPBN; (3) atropine + carbachol into the LV + moxonidine into the LPBN; (4) losartan + carbachol into the LV + moxonidine into the LPBN.

A recovery period of at least 2 days was allowed between tests.

\subsubsection{Tests in hyperosmotic rats}

Water, $0.3 \mathrm{M} \mathrm{NaCl}$ and food were removed from the cage and animals $(\mathrm{n}=19)$ received an ig load of $2 \mathrm{M} \mathrm{NaCl}(2 \mathrm{ml} / \mathrm{rat})$ followed by an icv injection of atropine $(20 \mathrm{nmol} / 1.0 \mu \mathrm{l})$, losartan $(100 \mu \mathrm{g} / 1.0 \mu \mathrm{l})$ or saline. Forty-five minutes after ig load, moxonidine $(0.5 \mathrm{nmol} / 0.2 \mu \mathrm{l})$ or vehicle was injected bilaterally into the LPBN. Fifteen minutes after moxonidine, animals had access to water and $0.3 \mathrm{M} \mathrm{NaCl}$ and cumulative intake was recorded at 15, 30, 60, 90 and $120 \mathrm{~min}$. The sequence of treatments into the LV and LPBN was randomized and each hyperosmotic rat received all four combinations of treatments: (1) saline into the LV + vehicle into the LPBN; (2) saline into the LV + moxonidine into the LPBN; (3) atropine into the LV + moxonidine into the LPBN; (4) losartan into the $\mathrm{LV}+$ moxonidine into the LPBN. A recovery period of at least 2 days was allowed between tests.

\subsection{Histology}

At the end of the last intake test, rats received injections of $2 \%$ Evans Blue solution into each site in the same volume used for drug injections. They were then deeply anesthetized with sodium thiopental ( $80 \mathrm{mg} / \mathrm{kg}$ of b. wt.; Cristália) and perfused transcardially with saline followed by $10 \%$ formalin. Brains were removed, fixed in $10 \%$ formalin, frozen, cut in $50 \mu \mathrm{m}$ sections, stained with Giemsa stain, and analyzed by light microscopy to confirm injection sites into the LPBN and LV.

\subsection{Statistical analysis}

Results are reported as means \pm SEM. Two-way analysis of variance (ANOVA) using treatments and times as factors followed by Student-Newman-Keuls tests was used for comparisons. Differences were considered significant at $\mathrm{P}<0.05$.

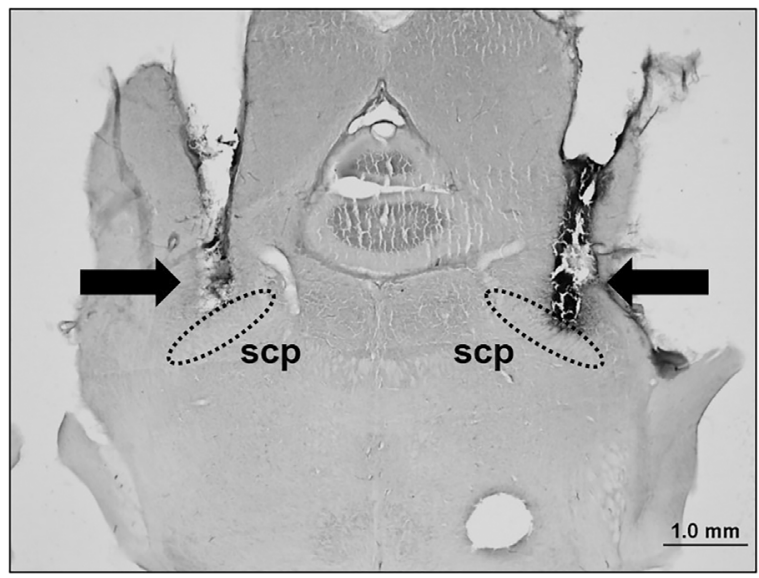

Fig. 1. Photomicrograph of coronal brain sections from an animal representative of the group tested showing (arrows) the typical site of injections into the LPBN. scp, superior cerebellar peduncle (delimited by dashed lines).

\section{Results}

\subsection{Histological analysis}

Fig. 1 shows the typical injection sites into the LPBN. The center of the LPBN injections was located in central and dorsal portions of the LPBN [see [42] for definitions of LPBN subnuclei]. The sites of the injection into the LPBN in the present study were similar to those of previous studies that showed effects of moxonidine into the LPBN on $\mathrm{NaCl}$ and water intake $[9,32,38,43-45]$. In 15 rats used in the study the histological analysis showed that the injections were not performed correctly into the LPBN. Data from these animals were not included in the analysis.

\subsection{FURO + CAP-induced water and $0.3 \mathrm{M} \mathrm{NaCl}$ intake in rats treated with moxonidine into the $L P B N$ combined with atropine icv}

In rats treated with saline icv, bilateral injections of moxonidine $(0.5 \mathrm{nmol} / 0.2 \mu \mathrm{l})$ into the LPBN increased FURO + CAP-induced water $(23.0 \pm 3.2 \mathrm{ml} / 2 \mathrm{~h}$, vs. vehicle into the LPBN: $8.9 \pm 1.0 \mathrm{ml} / 2 \mathrm{~h})[\mathrm{F}$ $(2,16)=10.04 ; \mathrm{P}<0,05]$ and $0.3 \mathrm{M} \mathrm{NaCl}$ intake $(27.8 \pm 4.8 \mathrm{ml} /$ $2 \mathrm{~h}$, vs. vehicle into the LPBN: $4.5 \pm 0.7 \mathrm{ml} / 2 \mathrm{~h})[\mathrm{F}(2,16)=14.05$; $\mathrm{P}<0$,05] (Fig. 2). The pre-treatment with icv injection of atropine (20 nmol/1 $\mu \mathrm{l}$ ) did not change FURO + CAP-induced $0.3 \mathrm{M} \mathrm{NaCl}$ intake $(27.5 \pm 3.8 \mathrm{ml} / 2 \mathrm{~h})$, but reduced water intake $(14.7 \pm 2.2 \mathrm{ml} / 2 \mathrm{~h})$ in rats treated with moxonidine injected into the LPBN (Fig. 2).

\subsection{Central ANG II-induced water and $0.3 \mathrm{M} \mathrm{NaCl}$ intake in rats treated with moxonidine into the $L P B N$ combined with atropine icv}

In rats that received injections of vehicle into the LPBN, the icv injection of ANG II $(50 \mathrm{ng} / 1 \mu \mathrm{l})$ induced water intake $(14.3 \pm 1.5 \mathrm{ml} /$ $2 \mathrm{~h})$ and only a small ingestion of $0.3 \mathrm{M} \mathrm{NaCl}(3.3 \pm 1.0 \mathrm{ml} / 2 \mathrm{~h})$ (Fig. 3). Bilateral injections of moxonidine $(0.5 \mathrm{nmol} / 0.2 \mu \mathrm{l})$ into the LPBN strongly increased icv ANG II-induced water $(25.2 \pm 2.5 \mathrm{ml} /$ $2 \mathrm{~h})[\mathrm{F}(2,16)=6.50 ; \mathrm{P}<0.05]$ and $0.3 \mathrm{M} \mathrm{NaCl}$ intake $(26.9 \pm 2.7 \mathrm{ml} / 2 \mathrm{~h})[\mathrm{F}(2,16)=26.81 ; \mathrm{P}<0.05]$ (Fig. 3). The pretreatment with icv injection of atropine $(20 \mathrm{nmol} / 1 \mu \mathrm{l})$ did not change ANG II-induced $0.3 \mathrm{M} \mathrm{NaCl}$ intake ( $23.6 \pm 3.9 \mathrm{ml} / 2 \mathrm{~h}$ ), but reduced water intake $(18.8 \pm 2.2 \mathrm{ml} / 2 \mathrm{~h})$ in rats that received injections of moxonidine into the LPBN (Fig. 3).

\subsection{Water and $0.3 \mathrm{M} \mathrm{NaCl}$ intake by hyperosmotic rats treated with} moxonidine into the LPBN combined with atropine or losartan icv

Bilateral injections of moxonidine $(0.5 \mathrm{nmol} / 0.2 \mu \mathrm{l})$ into the LPBN 


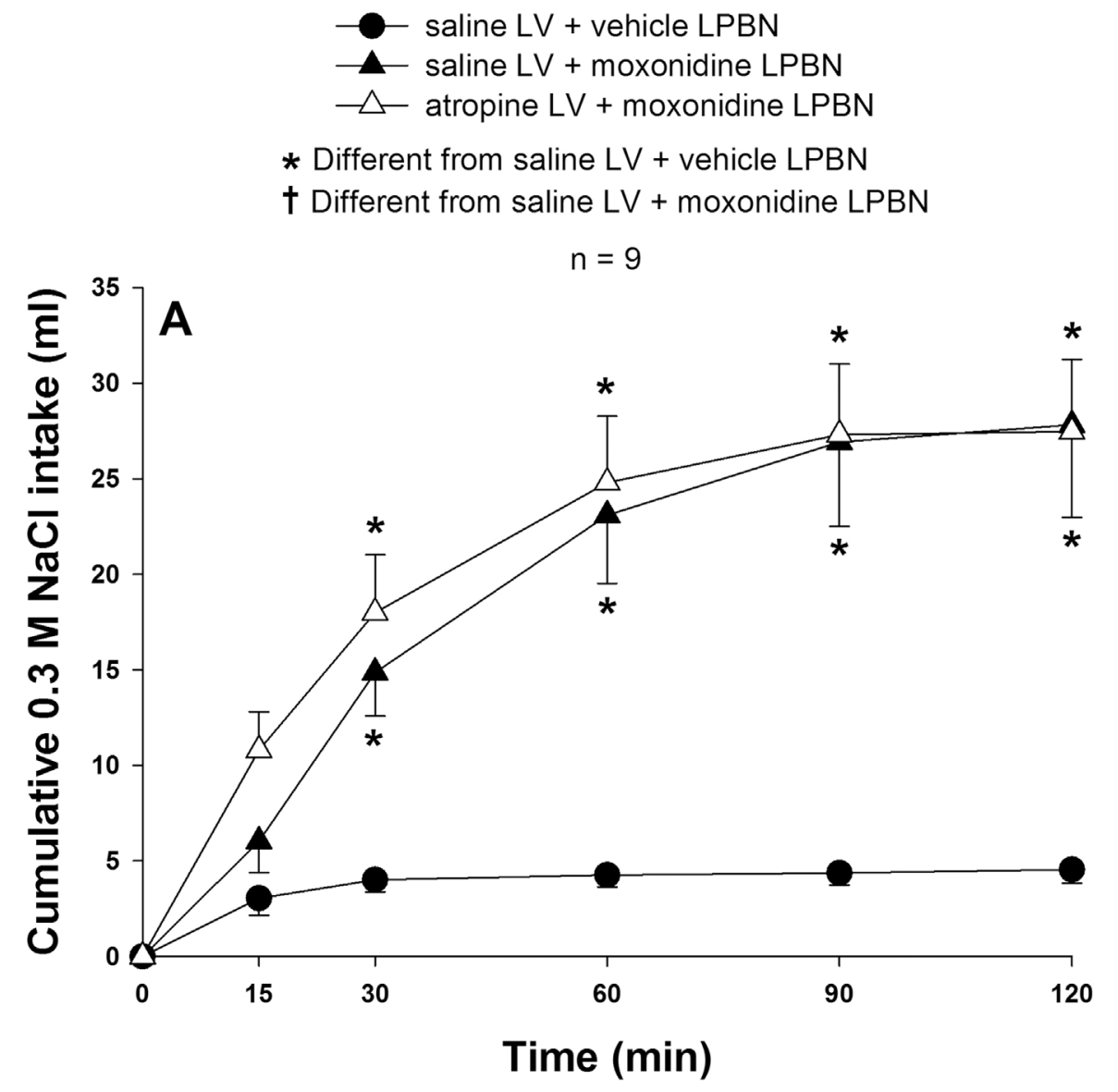

Fig. 2. Cumulative (A) $0.3 \mathrm{M} \mathrm{NaCl}$ and (B) water intake induced by FURO + CAP in rats that received bilateral injections of vehicle or moxonidine $(0.5 \mathrm{nmol} / 0.2 \mu \mathrm{l})$ into the LPBN combined with saline or atropine $(20 \mathrm{nmol} / 1.0 \mu \mathrm{l})$ into the LV. Values are reported as means \pm SEM; $n=$ number of animals.

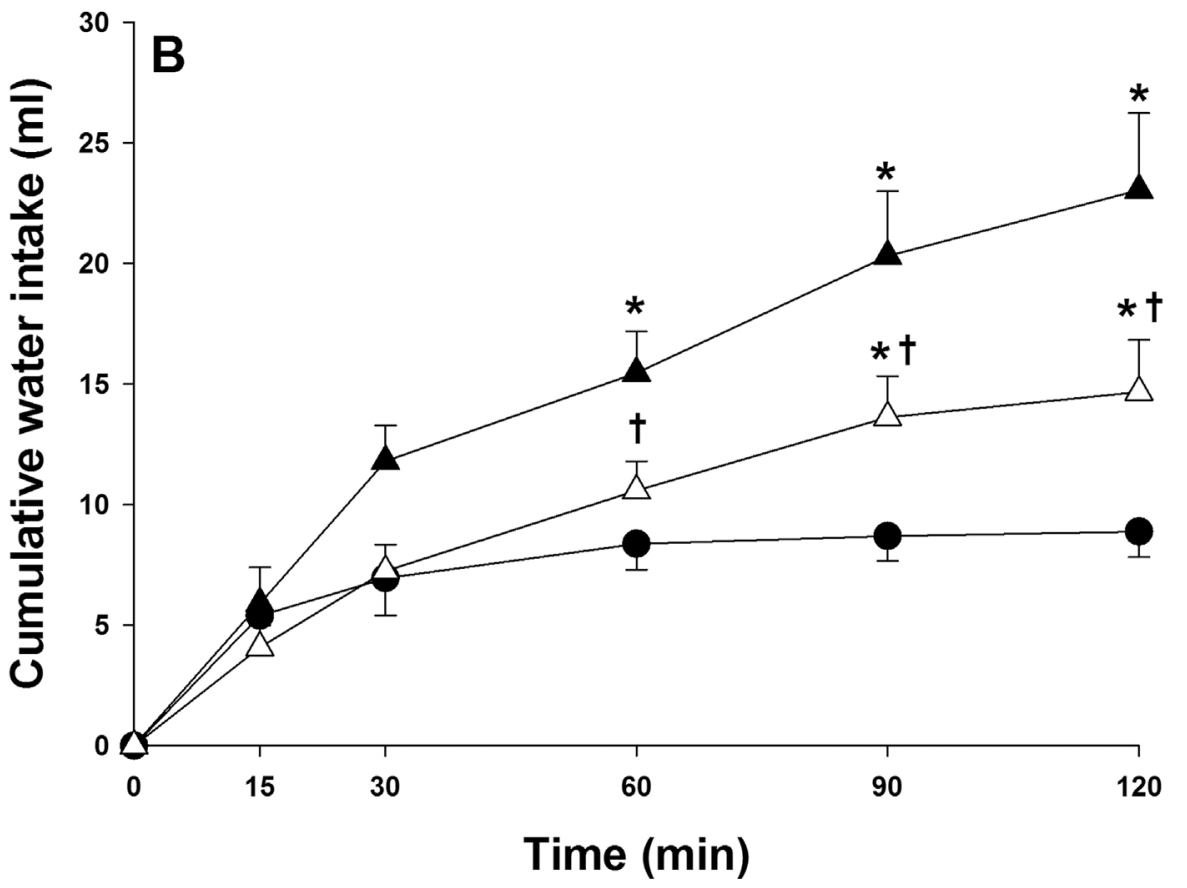

in rats treated with ig $2 \mathrm{M} \mathrm{NaCl}$ significantly increased water $(13.0 \pm 4.4 \mathrm{ml} / 2 \mathrm{~h}$, vs. vehicle into the LPBN: $6.9 \pm 1.0 \mathrm{ml} / 2 \mathrm{~h})[\mathrm{F}$ $(3,24)=7.00 ; \mathrm{P}<0.05]$ and $0.3 \mathrm{M} \mathrm{NaCl}$ intake $(18.6 \pm 5.2 \mathrm{ml} / 2 \mathrm{~h}$, vs. vehicle into the LPBN: $0.2 \pm 0.1 \mathrm{ml} / 2 \mathrm{~h})[\mathrm{F}(3,24)=10.96$; $\mathrm{P}<0.05$ ] (Fig. 4). The pre-treatment with icv injections of atropine $(20 \mathrm{nmol} / 1 \mu \mathrm{l})$ or losartan $(100 \mu \mathrm{g} / 1 \mu \mathrm{l})$ completely abolished water $(0.7 \pm 0.3$ and $0.9 \pm 0.8 \mathrm{ml} / 2 \mathrm{~h}$, respectively) and $0.3 \mathrm{M} \mathrm{NaCl}$ intake $(1.3 \pm 0.4$ and $0.6 \pm 0.3 \mathrm{ml} / 2 \mathrm{~h}$, respectively) induced by hyperosmolarity combined with moxonidine injected into the LPBN (Fig. 4).

3.5. Water and $0.3 \mathrm{M} \mathrm{NaCl}$ intake in rats treated with moxonidine into the $L P B N$ combined with carbachol + atropine or losartan icv

Carbachol $(4 \mathrm{nmol} / 1 \mu \mathrm{l})$ injected icv in normohydrated rats that received injections of vehicle into the LPBN produced water intake 


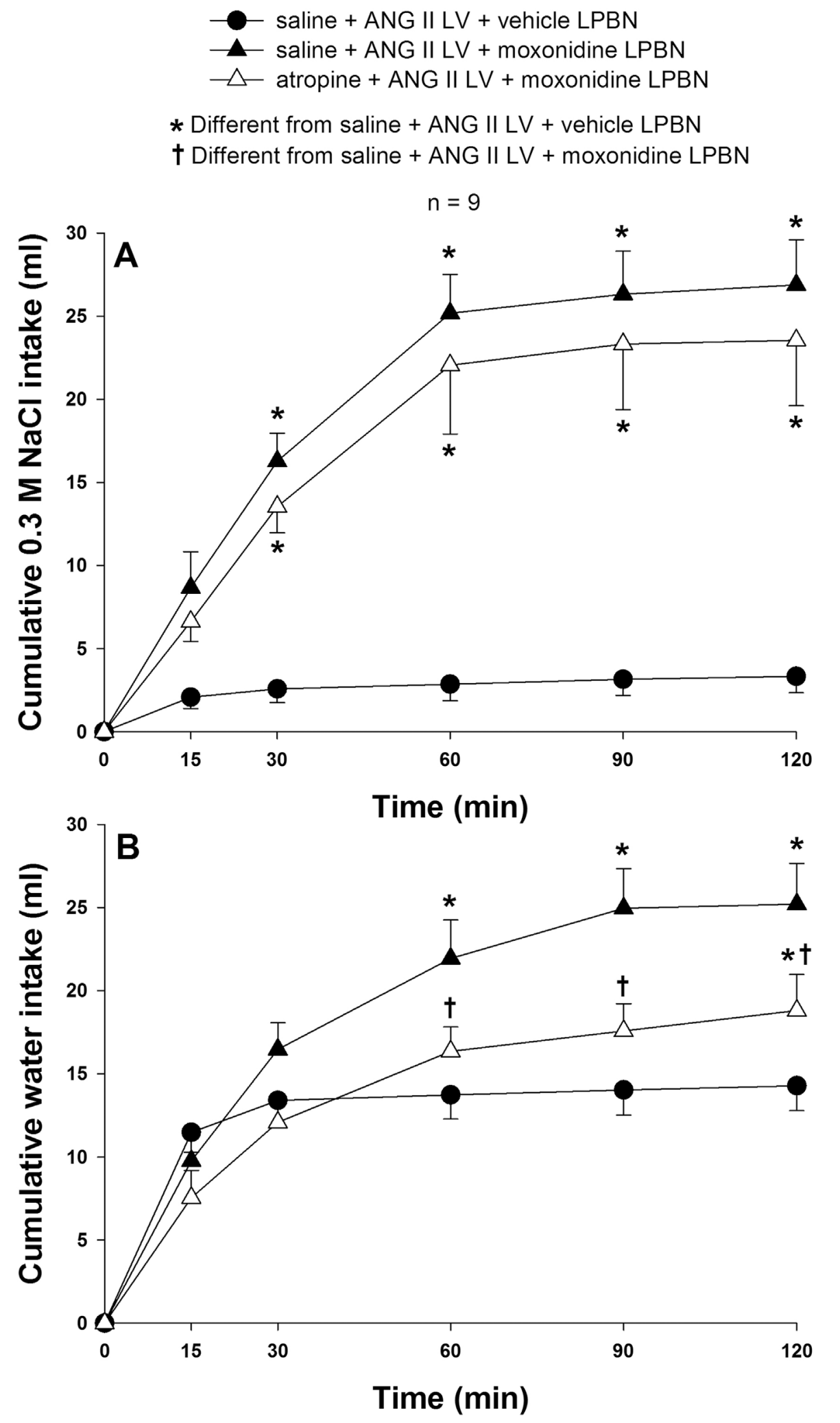

Fig. 3. Cumulative (A) $0.3 \mathrm{M} \mathrm{NaCl}$ and (B) water intake induced by ANG II $(50 \mathrm{ng} / 1.0 \mu \mathrm{l})$ injection into the $\mathrm{LV}$ of normohydrated rats treated with bilateral injections of vehicle or moxonidine $(0.5 \mathrm{nmol} / 0.2 \mu \mathrm{l})$ into the LPBN combined with saline or atropine $(20 \mathrm{nmol} / 1.0 \mu \mathrm{l})$ into the $\mathrm{LV}$. Values are reported as means \pm SEM; $\mathrm{n}=$ number of animals.
$(5.0 \pm 1.2 \mathrm{ml} / 2 \mathrm{~h})$ and only a small $0.3 \mathrm{M} \mathrm{NaCl}$ intake $(1.0 \pm 0.2 \mathrm{ml} /$ $2 \mathrm{~h})$. Bilateral injections of moxonidine $(0.5 \mathrm{nmol} / 0.2 \mu \mathrm{l})$ into the LPBN significantly increased water $(11.1 \pm 3.6 \mathrm{ml} / 2 \mathrm{~h})[\mathrm{F}(3,27)=7.98$; $\mathrm{P}<0.05]$ and $0.3 \mathrm{M} \mathrm{NaCl}$ intake $(16.6 \pm 5.8 \mathrm{ml} / 2 \mathrm{~h})[\mathrm{F}(3,27)$ $=6.12 ; \mathrm{P}<0.05]$ in rats treated with carbachol icv (Fig. 5). The pretreatment with icv injections of atropine $(20 \mathrm{nmol} / 1 \mu \mathrm{l})$ or losartan $(100 \mu \mathrm{g} / 1 \mu \mathrm{l})$ abolished water $(0.9 \pm 0.6$ and $1.2 \pm 0.6 \mathrm{ml} / 2 \mathrm{~h}$, respectively) and $0.3 \mathrm{M} \mathrm{NaCl}$ intake $(2.4 \pm 1.3$ and $4.0 \pm 2.0 \mathrm{ml} / 2 \mathrm{~h}$, respectively) in rats treated with carbachol icv combined with moxonidine into the LPBN (Fig. 5).

\section{Discussion}

The present results suggest the participation of ANG II on $0.3 \mathrm{M}$ 


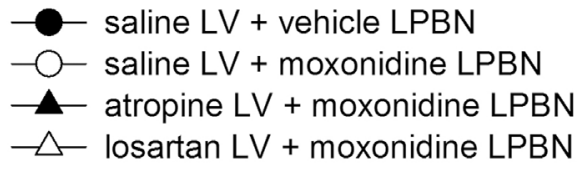

* Different from saline LV + vehicle LPBN

† Different from saline LV + moxonidine LPBN

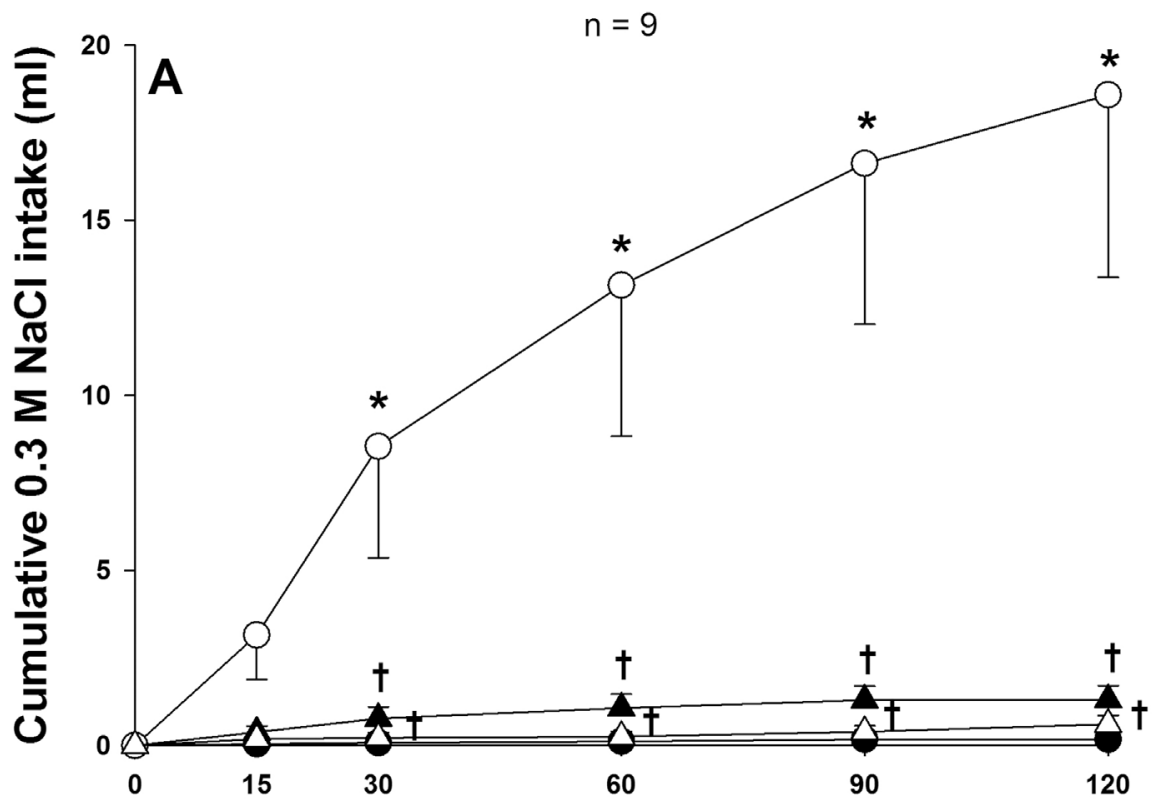

\section{Time (min)}

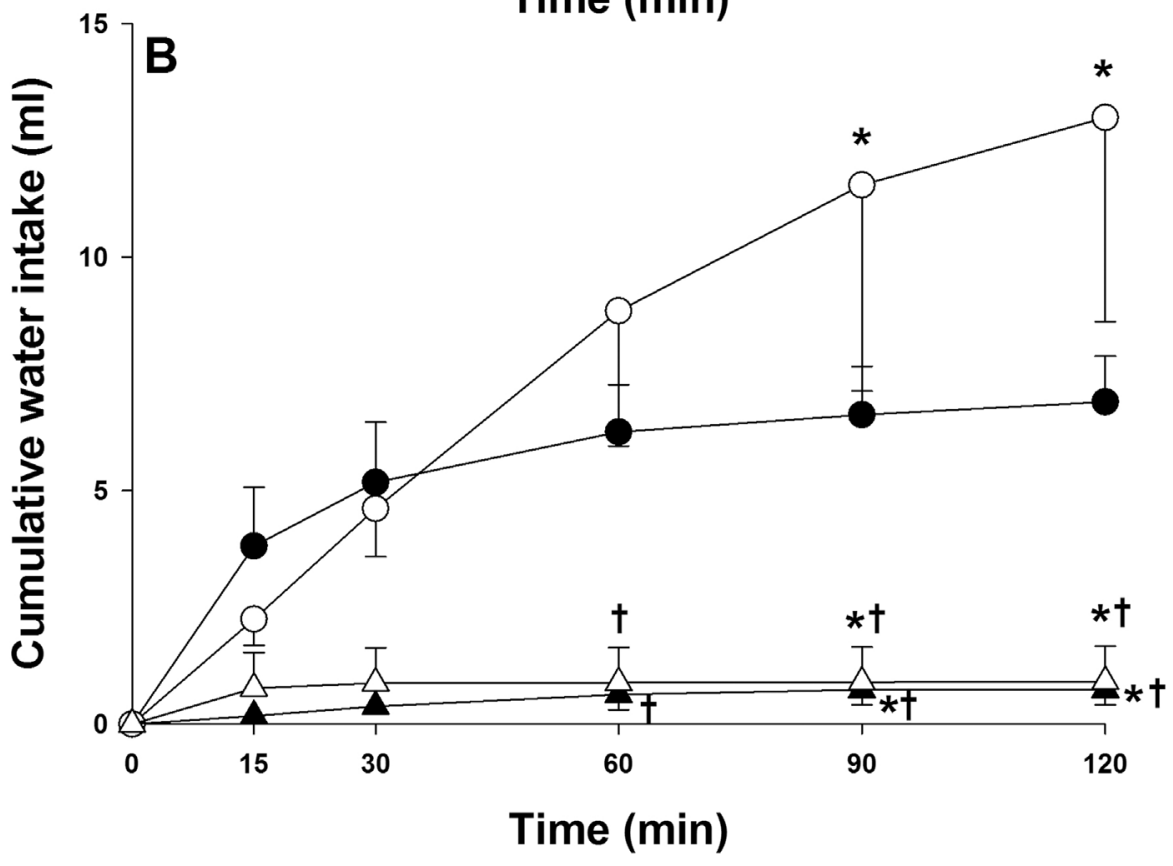

$\mathrm{NaCl}$ intake elicited by hyperosmolarity or brain injection of the cholinergic agonist carbachol combined with moxonidine injected into the LPBN. These results together with previous studies showing the importance of ANG II for sodium intake induced by hypovolemia combined or not with LPBN blockade [1,3-7,35,36,39,40,45,46] suggest ANG II as a common facilitatory mechanism to produce sodium intake when hypovolemia or hyperosmolarity was combined with the blockade of the LPBN inhibitory mechanism. In addition, similar to brain angiotensinergic mechanisms, the central cholinergic receptors
Fig. 4. Cumulative (A) $0.3 \mathrm{M} \mathrm{NaCl}$ and (B) water intake by rats treated with ig $2 \mathrm{M} \mathrm{NaCl}$ that received bilateral injections of vehicle or moxonidine $(0.5 \mathrm{nmol} / 0.2 \mu \mathrm{l})$ into the LPBN combined with saline, atropine $(20 \mathrm{nmol} / 1.0 \mu \mathrm{l})$ or losartan $(100 \mu \mathrm{g} / 1.0 \mu \mathrm{l})$ into the LV. Values are reported as means $\pm \mathrm{SEM} ; \mathrm{n}=$ number of animals. 
- - saline + carbachol LV + vehicle LPBN

$-O$ - saline + carbachol LV + moxonidine LPBN

- - atropine + carbachol LV + moxonidine LPBN

$\triangle \smile$ losartan + carbachol LV + moxonidine LPBN

* Different from saline + carbachol LV + vehicle LPBN

† Different from saline + carbachol LV + moxonidine LPBN
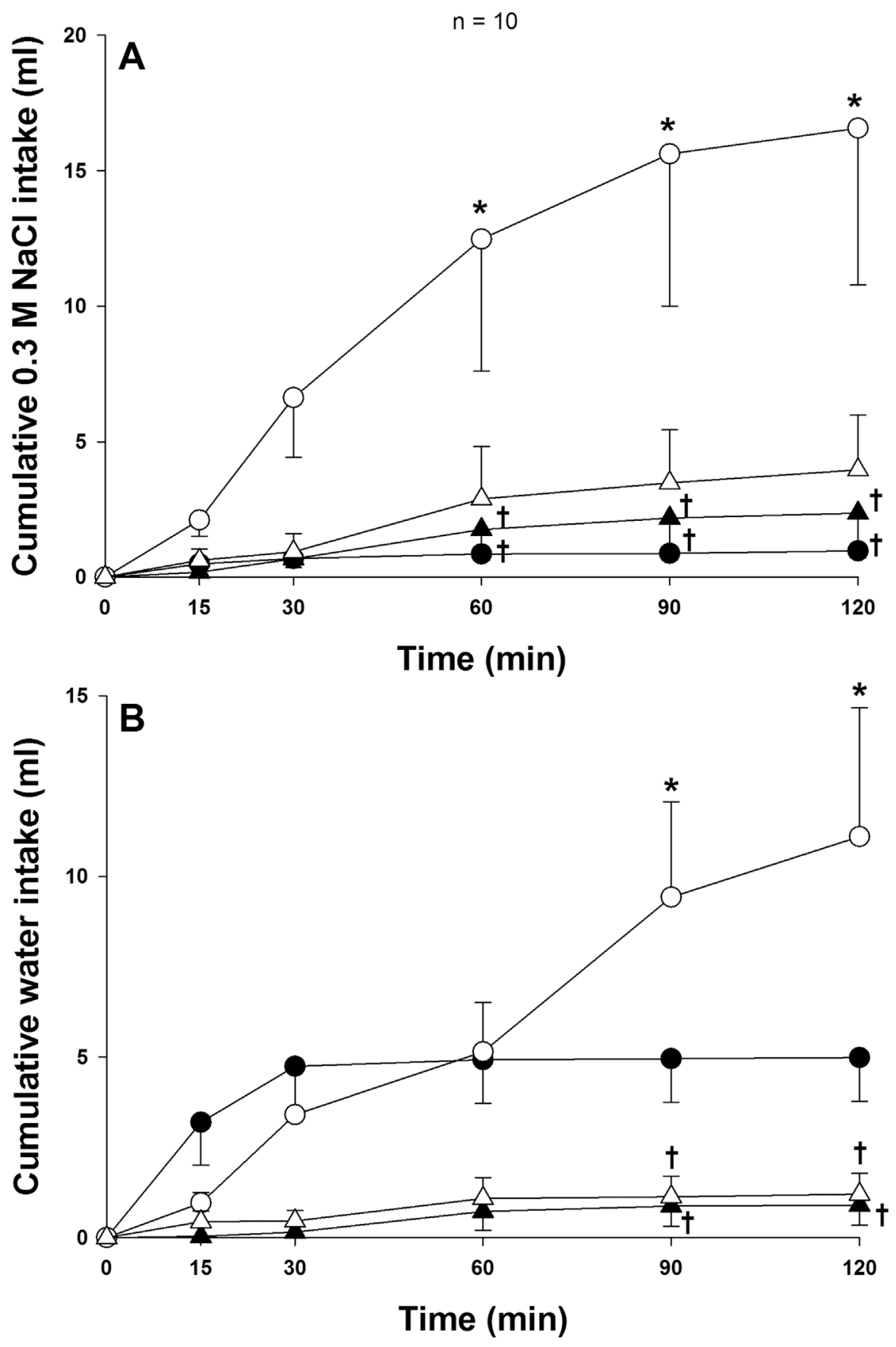

sodium intake [44]. The present results extend those of previous studies showing that injections of moxonidine into the LPBN also increase water and $0.3 \mathrm{M} \mathrm{NaCl}$ intake in rats treated with central ANG II or carbachol, which reinforces the suggestion that $\alpha_{2}$ adrenergic activation in the LPBN is an important modulator of LPBN inhibitory mechanism. In spite of the strong increase of sodium intake when combined with different dipsogenic or natriorexigenic stimuli, injections of
Fig. 5. Cumulative (A) $0.3 \mathrm{M} \mathrm{NaCl}$ and (B) water intake induced by carbachol $(4 \mathrm{nmol} / 1.0 \mu \mathrm{l})$ injection into the $\mathrm{LV}$ of normohydrated rats treated with bilateral injections of vehicle or moxonidine $(0.5 \mathrm{nmol} / 0.2 \mu \mathrm{l})$ into the LPBN combined with saline, atropine $(20 \mathrm{nmol} / 1.0 \mu \mathrm{l})$ or losartan $(100 \mu \mathrm{g} / 1.0 \mu \mathrm{l})$ into the $\mathrm{LV}$. Values are reported as means $\pm S E ; n=$ number of animals. moxonidine alone into the LPBN without any additional treatment produce no change on sodium intake. This demonstrates that moxonidine injected into the LPBN has per se no facilitatory action on sodium intake [32].

The increased plasma osmolarity due to ingestion of hypertonic $\mathrm{NaCl}$ may stimulate ingestion of water when water and $0.3 \mathrm{M} \mathrm{NaCl}$ are simultaneously available (two bottle test). Thus, reduced ingestion of 


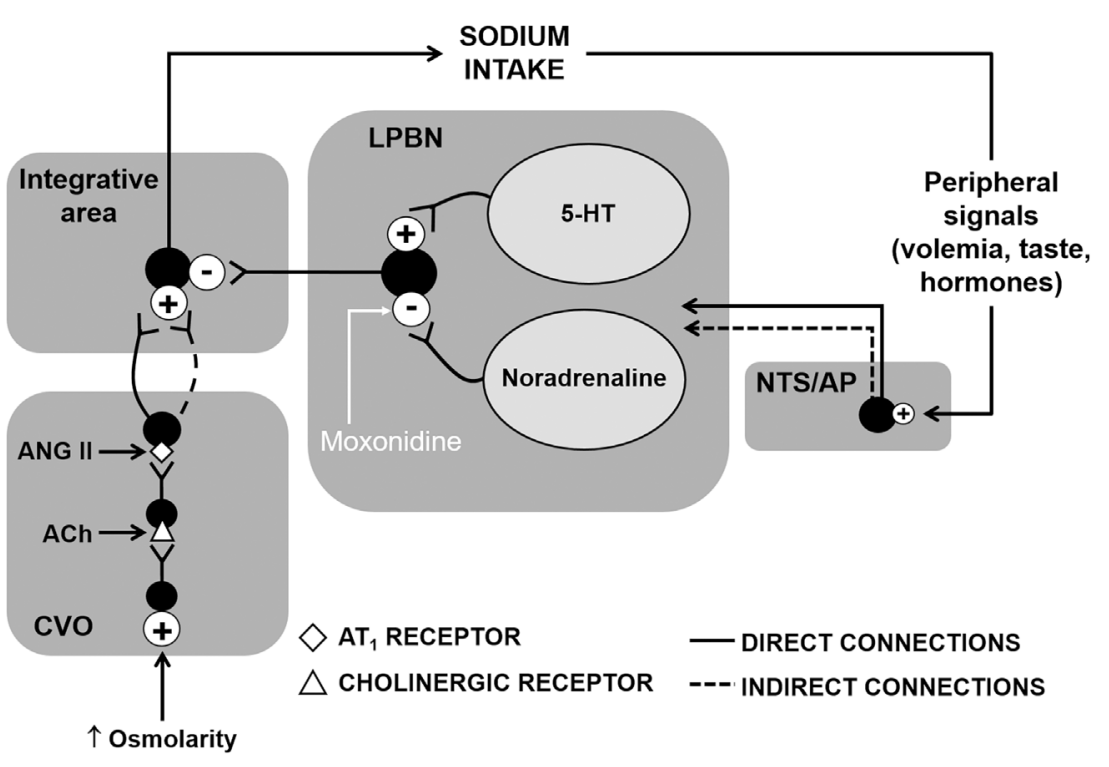

Fig. 6. Schematic model showing possible mechanisms involved in the control of sodium intake in a condition of hyperosmolarity. An integrative area receives inhibitory signals from the LPBN and facilitatory signals produced by osmoreceptor activation that affect sodium intake. Different neurotransmitters, among them noradrenaline acting on $\alpha_{2}$ adrenoceptor or serotonin modulate the inhibitory mechanisms in the LPBN. Osmoreceptors activate a pathway involving cholinergic and finally angiotensinergic mechanisms to release facilitatory signals for sodium intake. Sodium intake is stimulated in a condition of hyperosmolarity only if the inhibitory mechanisms are deactivated, like when moxonidine is injected into the LPBN. 5-HT, serotonin; LPBN, lateral parabrachial nucleus; CVO, circumventricular organs; ANG II, angiotensin II; ACh, acetylcholine; NTS/AP, nucleus of the solitary tract/area postrema. water after central angiotensinergic or cholinergic blockade in rats treated with moxonidine into the LPBN in some cases might be a consequence of reduced ingestion of hypertonic $\mathrm{NaCl}$. However, reduction in water intake also occurred without significant changes in $\mathrm{NaCl}$ intake when atropine was injected icv in rats treated with FURO + CAP sc or ANG II icv. This reduction confirms previous suggestions that water intake depends also on the activation of central cholinergic mechanisms in addition to central angiotensinergic mechanisms $[20,47,48]$.

ANG II is a peptide clearly involved in the control of water intake and $\mathrm{NaCl}$ intake $[1,46]$. The activation of central angiotensinergic mechanisms induces a gradual and slow developing $\mathrm{NaCl}$ intake $[1,49]$. However, after the blockade of the LPBN with moxonidine or the serotonergic agonist methysergide, ANG II icv causes an immediate and intense $0.3 \mathrm{M} \mathrm{NaCl}$ intake [36]. Methysergide, like moxonidine, injected into the LPBN also significantly increases $0.3 \mathrm{M} \mathrm{NaCl}$ intake in rats treated with FURO + CAP [32,36,40,41]. In addition to ANG II, hyperosmolarity and central cholinergic stimulation, classically known as dipsogenic and anti-natriorexigenic stimuli, may also produce facilitatory signals for sodium intake in addition to the usual inhibitory signals $[9,26,27,29,38,39]$. An increase in plasma osmolarity produced by an ig load of $2 \mathrm{M} \mathrm{NaCl}$ facilitates $0.3 \mathrm{M} \mathrm{NaCl}$ intake in addition to the usual water intake provided that LPBN inhibitory mechanisms are blocked by bilateral injections of methysergide or moxonidine [38,39]. This suggests that hyperosmolarity also activates mechanisms that facilitate sodium appetite, nevertheless, concurrent activation of LPBN inhibitory mechanisms would counteract this facilitatory effect, restraining $\mathrm{NaCl}$ intake [39]. Carbachol icv, besides thirst, also facilitates $\mathrm{NaCl}$ intake when combined with LPBN injections of methysergide [26] or moxonidine (present study), which suggests that similar to hyperosmolarity, central cholinergic activation may also produce facilitatory signals for sodium intake in addition to the usual inhibitory signals.

The blockade of central $\mathrm{AT}_{1}$ receptors abolishes sodium intake in rats treated with ANG II or FURO + CAP combined with the blockade of the LPBN mechanisms or not $[37,41,50,51]$. However, as shown by the present results, the blockade of central cholinergic mechanisms with atropine did not modify sodium intake in rats treated with ANG II icv or FURO + CAP sc combined with moxonidine into the LPBN, suggesting that cholinergic mechanisms are not part of the pathway activated by ANG II to facilitate sodium intake. These results are similar to those of previous studies showing that cholinergic antagonists do not change or only partially reduce ANG II-induced pressor response and thirst $[20,47,48]$. On the other hand, losartan injected icv also abolished water and $\mathrm{NaCl}$ intake in rats that received carbachol icv combined with moxonidine into the LPBN, which suggests that central cholinergic stimulation depends on the activation of angiotensinergic mechanisms to facilitate water and $\mathrm{NaCl}$ intake. The present results also show that atropine or losartan injected icv abolished water and $0.3 \mathrm{M}$ $\mathrm{NaCl}$ in rats treated with ig $2 \mathrm{M} \mathrm{NaCl}$ combined with moxonidine into the LPBN, which suggests that cholinergic and angiotensinergic mechanisms are activated by hyperosmolarity to facilitate sodium intake in this condition.

The importance of $\mathrm{AT}_{1}$ receptors was previously demonstrated for hyperosmolarity-induced natriuresis, vasopressin secretion, pressor response and c-Fos expression in the median preoptic nucleus, paraventricular nucleus and supraoptic nucleus [21,22,24,52]. The present results extend those of previous studies suggesting that hyperosmolarity also activates angiotensinergic mechanisms to facilitate sodium intake. Fig. 6 is a schematic model that illustrates the possible interaction between the facilitatory mechanism activated by hyperosmolarity in the forebrain and the LPBN inhibitory mechanisms for the control of sodium intake. Facilitatory and inhibitory signals involved in the control of sodium intake may reach an integrative area that perhaps is the central nucleus of the amygdala [43]. Osmoreceptors activate a pathway involving cholinergic and finally angiotensinergic mechanisms to release facilitatory signals for sodium intake in the integrative area. The LPBN receives signals from the nucleus of the solitary tract/area postrema that arise from peripheral baroreceptors and other systemic visceral receptors including osmoreceptors and taste receptors. These signals release different neurotransmitters, among them noradrenaline acting on $\alpha_{2}$ adrenoceptor or serotonin that modulate the activity of the LPBN. The facilitatory signals produced by hyperosmolarity are completely blocked by the activity of the LPBN inhibitory mechanisms and no sodium is ingested by hyperosmotic animals. Moxonidine deactivates the LPBN inhibitory mechanisms releasing the action of the facilitatory signals produced by osmoreceptor activation as the first step and ANG II release as the last and common step for different stimuli to facilitate sodium intake. At least cholinergic mechanisms are also part of the pathway activated by osmoreceptor to induce sodium intake, however, it is not possible to completely exclude the involvement of other neurotransmitters in this pathway.

Although the present results suggest an interaction between cholinergic and angiotensinergic mechanisms to facilitate sodium intake, previous studies about the interaction between cholinergic and angiotensinergic mechanisms have shown controversial results. The antagonism of $\mathrm{AT}_{1}$ receptors abolished the pressor response and natriuresis to carbachol icv, while other studies suggested that the inhibition of angiotensinergic mechanisms did not change the responses to cholinergic stimulation $[18,19]$. Particularly for sodium intake, according to the 
classical concepts it was not expected interaction between cholinergic and angiotensinergic mechanisms. In the classical view, hyperosmolarity and central cholinergic mechanisms should oppose the action of angiotensinergic mechanisms in the control of sodium intake $[14,49,53]$. Contrary to these classical concepts, the present results are the first to suggest interactions between cholinergic and angiotensinergic mechanisms in the control of sodium intake with the central angiotensinergic mechanisms as the final common pathway to facilitate sodium intake as shown in Fig. 6. Therefore, the activation of $\mathrm{AT}_{1}$ receptors by ANG II is a necessary step to facilitate sodium intake if the initial stimulus is fluid depletion, hyperosmolarity or central cholinergic activation.

In conclusion, the present results show that central cholinergic and angiotensinergic mechanisms are activated by hyperosmolarity to facilitate sodium intake, a behavior clearly expressed by the ingestion of significant amount of sodium when the LPBN mechanisms are deactivated. The cholinergic mechanisms depend on angiotensinergic mechanisms to facilitate sodium. The results suggest that central angiotensinergic is the final common mechanism activated by different dipsogenic/natriorexigenic stimuli including hyperosmolarity and central cholinergic activation to facilitate sodium intake. This reinforces the importance of ANG II and LPBN mechanisms for the control of sodium intake and again suggests that to reduce inhibition is as important as to increase facilitatory signals to induce sodium intake.

\section{Acknowledgments}

The authors thank Silas P. Barbosa, Reginaldo C. Queiroz and Silvia Fóglia for expert technical assistance, Silvana A. D. Malavolta and Carla D. M. de Alencar for secretarial assistance, Adriano P. de Oliveira and Ana V. de Oliveira for animal care. This research was supported by Brazilian public funding from FAPESP, CNPq and CAPES. This study was part of the activities developed by Camila F. Roncari to obtain a $\mathrm{PhD}$ degree at the Joint Graduate Program in Physiological Sciences (PIPGCF) from UFSCar/UNESP.

\section{References}

[1] J.T. Fitzsimons, Angiotensin, thirst, and sodium appetite, Physiol. Rev. 78 (1998) 583-686.

[2] S. Formenti, M. Bassi, N.B. Nakamura, G.H. Schoorlemmer, J.V. Menani, E. Colombari, Hindbrain mineralocorticoid mechanisms on sodium appetite, Am. J. Physiol. Regul. Integr. Comp. Physiol. 304 (2013) R252-9.

[3] A.K. Johnson, R.L. Thunhorst, The neuroendocrinology of thirst and salt appetite: visceral sensory signals and mechanisms of central integration, Front. Neuroendocrinol. 18 (1997) 292-353.

[4] J.V. Menani, L.A. De Luca Jr., A.K. Johnson, Role of the lateral parabrachial nucleus in the control of sodium appetite, Am. J. Physiol. Regul. Integr. Comp. Physiol. 306 (2014) R201-R210.

[5] A.K. Johnson, R.L. Thunhorst, The Neuroendocrinology, Neurochemistry and Molecular Biology of Thirst and Salt Appetite. Handbook of Neurochemistry and Molecular Neurobiology: Behavioral Neurochemistry, Neuroendocrinology and Molecular Neurobiology, Springer, New York, 2007, pp. 641-687.

[6] J. Antunes-Rodrigues, M. de Castro, L.L. Elias, M.M. Valenca, S.M. McCann, Neuroendocrine control of body fluid metabolism, Physiol. Rev. 84 (2004) 169-208.

[7] M.J. McKinley, A.K. Johnson, The physiological regulation of thirst and fluid intake, News Physiol. Sci. 19 (2004) 1-6.

[8] D.T. Pereira, R.C. Vendramini, R.B. David, P.N. Nozaki, J.V. Menani, L.A. De Luca Jr., Isotonic $\mathrm{NaCl}$ intake by cell-dehydrated rats, Physiol. Behav. 76 (2002) 501-505.

[9] C.A.F. Andrade, L.O. Margatho, G.M. Andrade-Franze, L.A. De Luca Jr., J. AntunesRodrigues, J.V. Menani, Moxonidine into the lateral parabrachial nucleus reduces renal and hormonal responses to cell dehydration, Neuroscience 208 (2012) 69-78.

[10] A. Gilman, The relation between blood osmotic pressure, fluid distribution and voluntary water intake, Am. J. Physiol. 120 (1937) 323-328.

[11] R.E. Blackburn, W.K. Samson, R.J. Fulton, E.M. Stricker, J.G. Verbalis, Central oxytocin inhibition of salt appetite in rats: evidence for differential sensing of plasma sodium and osmolality, Proc. Natl. Acad. Sci. U. S. A. 90 (1993) 10380-10384.

[12] A. Routtenberg, J.B. Simpson, Carbachol-induced drinking at ventricular and subfornical organ sites of application, Life Sci. I. 10 (1971) 481-490.

[13] J.B. Simpson, A. Routtenberg, Subfornical organ: acetylcholine application elicits drinking, Brain Res. 79 (1974) 157-164.
[14] D.A. Fitts, R.L. Thunhorst, J.B. Simpson, Modulation of salt appetite by lateral ventricular infusions of angiotensin II and carbachol during sodium depletion, Brain Res. 346 (1985) 273-280.

[15] W.J. Lee, K.S. Kim, E.K. Yang, J.H. Lee, E.J. Lee, J.S. Park, et al., Effect of brain angiotensin $\mathrm{II} \mathrm{AT}_{1}, \mathrm{AT}_{2}$, and cholinergic receptor antagonism on drinking in waterdeprived rats, Regul. Pept. 66 (1996) 41-46.

[16] M.L. Block, A.E. Fisher, Anticholinergic central blockade of salt-aroused and deprivation-induced drinking, Physiol. Behav. 5 (1970) 525-527.

[17] L.C. Reis, W.A. Saad, L.A. Camargo, A. Renzi, J.V. Menani, Effect of a non-peptide angiotensin receptor antagonist on water intake caused by centrally administered carbachol in the rat, Braz. J. Med. Biol. Res. 29 (1996) 245-247.

[18] W.A. Saad, A.C. Luiz, L.A. Camargo, J.E. Silveira, S. Foglia, J.V. Menani, et al., Functional evidence that the central renin-angiotensin system plays a role in the pressor response induced by central injection of carbachol, Braz. J. Med. Biol. Res. 30 (1997) 493-496.

[19] M. Wang, C.L. Jiang, C.Y. Wang, Q.Y. Yao, Role of brain angiotensin $\mathrm{AT}_{1}$ receptor in the carbachol-induced natriuresis and expression of nNOS in the locus coeruleus and proximal convoluted tubule, Physiol. Res. 56 (2007) 383-391.

[20] K. Yamaguchi, H. Hama, Evaluation for roles of periventricular cholinoceptors in vasopressin secretion in response to angiotensin II and an osmotic stimulus, Brain Res. 496 (1989) 345-350.

[21] D.C. Hogarty, D.N. Tran, M.I. Phillips, Involvement of angiotensin receptor subtypes in osmotically induced release of vasopressin, Brain Res. 637 (1994) 126-132.

[22] E. Moellenhoff, C.J. Lebrun, A. Blume, J. Culman, T. Herdegen, T. Unger, Central angiotensin AT1 and muscarinic receptors in ITF expression on intracerebroventricular NaCl, Am. J. Physiol. 275 (1998) R234-44.

[23] P. Rohmeiss, C. Beyer, E. Nagy, C. Tschope, S. Hohle, M. Strauch, et al., NaCl injections in brain induce natriuresis and blood pressure responses sensitive to ANG II AT1 receptors, Am. J. Physiol. 269 (1995) F282-8.

[24] M.A. Tiruneh, B.S. Huang, F.H. Leenen, Role of angiotensin II type 1 receptors in the subfornical organ in the pressor responses to central sodium in rats, Brain Res. 1527 (2013) 79-86.

[25] W.A. Saad, A.C. Luiz, L.A. Camargo, A. Renzi, J.V. Menani, Saad W.A. Losartan, (DUP-753) blocks the natriuretic, kaliuretic and antidiuretic effect of intracerebroventricular injection of carbachol in water-loaded rats, Braz. J. Med. Biol. Res. 29 (1996) 511-513.

[26] J.V. Menani, S.P. Barbosa, L.A. De Luca Jr., J.I.F. De Gobbi, A.K. Johnson, Serotonergic mechanisms of the lateral parabrachial nucleus and cholinergic-induced sodium appetite, Am. J. Physiol. Regul. Integr. Comp. Physiol. 282 (2002) R837-R841.

[27] D.S. Asnar, C.F. Roncari, L.A. De Luca Jr., P.M. de Paula, D.S. Colombari, J.V. Menani, Involvement of central cholinergic mechanisms on sodium intake in duced by gabaergic activation of the lateral parabrachial nucleus, Neurosci. Lett. 534 (2013) 188-192.

[28] C.F. Roncari, R.B. David, P.M. De Paula, D.S. Colombari, L.A. De Luca Jr. J.V. Menani, Importance of central $\mathrm{AT}_{1}$ receptors for sodium intake induced by GABAergic activation of the lateral parabrachial nucleus, Neuroscience 196 (2011) $147-152$.

[29] C.F. Roncari, R.B. David, R.F. Johnson, P.M. De Paula, D.S. Colombari, L.A. De Luca Jr.et al., Angiotensinergic and cholinergic receptors of the subfornical organ mediate sodium intake induced by GABAergic activation of the lateral parabrachial nucleus, Neuroscience 262 (2014) 1-8.

[30] C.G. Pavan, C.F. Roncari, S.P. Barbosa, P.M. De Paula, D.S. Colombari, L.A. De Luca Jr.et al., Activation of $\mu$ opioid receptors in the LPBN facilitates sodium intake in rats, Behav. Brain Res. 288 (2015) 20-25.

[31] M.F. Menezes, S.P. Barbosa, C.A. De Andrade, J.V. Menani, P.M. De Paula, Purinergic mechanisms of lateral parabrachial nucleus facilitate sodium depletioninduced $\mathrm{NaCl}$ intake, Brain Res. 1372 (2011) 49-58.

[32] C.A.F. Andrade, S.P. Barbosa, L.A. De Luca Jr., J.V. Menani, Activation of $\alpha_{2}$ adrenergic receptors into the lateral parabrachial nucleus enhances $\mathrm{NaCl}$ intake in rats, Neuroscience 129 (2004) 25-34.

[33] J.C. Callera, L.B. De Oliveira, S.P. Barbosa, D.S.A. Colombari, L.A. De Luca Jr., J.V. Menani, GABA $A_{A}$ receptor activation in the lateral parabrachial nucleus induces water and hypertonic $\mathrm{NaCl}$ intake, Neuroscience 134 (2005) 725-735.

[34] L.B. De Oliveira, E.H. Kimura, J.C. Callera, L.A. De Luca Jr., D.S.A. Colombari, J.V. Menani, Baclofen into the lateral parabrachial nucleus induces hypertonic sodium chloride and sucrose intake in rats, Neuroscience 183 (2011) 160-170.

[35] J.I.F. De Gobbi, L.A. De Luca Jr., J.V. Menani, Serotonergic mechanisms of the lateral parabrachial nucleus on DOCA-induced sodium intake, Brain Res. 880 (2000) 131-138.

[36] J.V. Menani, R.L. Thunhorst, A.K. Johnson, Lateral parabrachial nucleus and serotonergic mechanisms in the control of salt appetite in rats, Am. J. Physiol. 270 (1996) R162-8.

[37] D.S.A. Colombari, J.V. Menani, A.K. Johnson, Forebrain angiotensin type 1 receptors and parabrachial serotonin in the control of $\mathrm{NaCl}$ and water intake, Am. J. Physiol. 271 (1996) R1470-6.

[38] C.A.F. Andrade, L.A. De Luca Jr., D.S.A. Colombari, J.V. Menani, Alpha activation in the lateral parabrachial nucleus induces $\mathrm{NaCl}$ intake under conditions of systemic hyperosmolarity, Neuroscience 142 (2006) 21-28.

[39] L.A. De Luca Jr., S.P. Barbosa, J.V. Menani, Brain serotonin blockade and paradoxical salt intake in rats, Neuroscience 121 (2003) 1055-1061.

[40] D.A. Fitts, D.B. Masson, Forebrain sites of action for drinking and salt appetite to angiotensin or captopril, Behav. Neurosci. 103 (1989) 865-872.

[41] R.L. Thunhorst, Johnson A.K. Renin-angiotensin, arterial blood pressure, and salt appetite in rats, Am. J. Physiol. 266 (1994) R458-65.

[42] C.E. Fulwiler, C.B. Saper, Subnuclear organization of the efferent connections of the 
parabrachial nucleus in the rat, Brain Res. 319 (1984) 229-259.

[43] G.M. Andrade-Franzé, C.A.F. Andrade, L.A. De Luca Jr., P.M. De Paula, J.V. Menani, Lateral parabrachial nucleus and central amygdala in the control of sodium intake, Neuroscience 165 (2010) 633-641.

[44] C.A.F. Andrade, G.M.F. Andrade-Franze, L.A. De Luca Jr., A.K. Johnson, J.V. Menani, Changes in taste reactivity to intra-oral hypertonic $\mathrm{NaCl}$ after lateral parabrachial injections of an $\alpha_{2}$-adrenergic receptor agonist, Physiol. Behav. 104 (2011) 702-708.

[45] C.A.F. Andrade, L.A. De Luca Jr., D.S.A. Colombari, J.V. Menani, Enhancement of meal-associated hypertonic $\mathrm{NaCl}$ intake by moxonidine into the lateral parabrachial nucleus, Behav. Brain Res. 183 (2007) 156-160.

[46] A.N. Epstein, J.T. Fitzsimons, B.J. Rolls, Drinking induced by injection of angiotensin into the brain of the rat, J. Physiol. 210 (1970) 457-474.

[47] M.L. Mangiapane, J.B. Simpson, Pharmacologic independence of subfornical organ receptors mediating drinking, Brain Res. 178 (1979) 507-517.

[48] J.T. Fitzsimons, P.E. Setler, The relative importance of central nervous catecholaminergic and cholinergic mechanisms in drinking in response to antiotensin and other thirst stimuli, J. Physiol. 250 (1975) 613-631.

[49] D.B. Avrith, J.T. Fitzsimons, Increased sodium appetite in the rat induced by intracranial administration of components of the renin-angiotensin system, J. Physiol. 301 (1980) 349-364.

[50] J.V. Menani, D.S.A. Colombari, T.G. Beltz, R.L. Thunhorst, A.K. Johnson, Salt appetite: interaction of forebrain angiotensinergic and hindbrain serotonergic mechanisms, Brain Res. 801 (1998) 29-35.

[51] M.J. Beresford, J.T. Fitzsimons, Intracerebroventricular angiotensin II-induced thirst and sodium appetite in rat are blocked by the AT1 receptor antagonist, Losartan (DuP 753), but not by the AT2 antagonist, CGP 42112B, Exp. Physiol. 77 (1992) 761-764.

[52] P. Rohmeiss, C. Beyer, B. Hocher, F. Qadri, N. Gretz, M. Strauch, et al., Osmotically induced natriuresis and blood pressure response involves angiotensin AT1 receptors in the subfornical organ, J. Hypertens. 13 (1995) 1399-1404.

[53] J.T. Fitzsimons, L.M. Fuller, Effects of angiotensin or carbachol on sodium intake and excretion in adrenalectomized or deoxycorticosterone-treated rats, J. Physiol. 359 (1985) 447-458. 